\title{
A gazdaság szektorainak és munkavállalóinak vizsgálata a digitális kompetencia szintek vonatkozásában az EU tagállamaiban
}

\section{Examining the Employees and Sectors of the Economy According to the Digital Competence in the EU Member} States

\author{
A. CSORDÁS \\ Debreceni Egyetem, Gazdaságtudományi Kar, Üzleti Informatikai Tanszék, \\ csordas.adrian@econ.unideb.hu
}

Absztrakt. A tanulmány első sorban az OECD, az Eurostat és a World Bank adatai alapján az EU tagállamainak a digitális fejlődéshez kapcsolódó kihívásait és a fejlettség szektoriális hatásait vizsgálja 2015 és 2017 között. Arra keresi a választ, hogy van-e kapcsolat az országok digitális fejlettsége és a szektorok dominanciája között. Azt tapasztaltam -nemzetközi kutatásokkal összhangban-, hogy azokban az országokban, amelyek a fejlett csoporthoz tartoznak, ott a magas hozzáadott értéket képviselő szolgáltatás szektor a meghatározó. Más kutatásokkal megegyezően, a fejlődő országok esetében a statisztikai vizsgálat alátámasztotta azt a feltételezést, hogy az ipar a gazdaság motorja. A fejletlen országok elemzésekor pedig az derült ki, hogy a többi országhoz viszonyítva a mezögazdaság és az ipar a hangsúlyos szektorok. A fejlett országok ICT szakemberekre irányuló igényét mérve, megvizsgáltam, hogy miként viszonyulnak a különböző digitális kompetenciájú egyének az önképzés egyik XXI. századi változatához, vagyis az online tanfolyamokhoz. Azt tapasztaltam -külföldi kutatásokkal összhangban-, hogy a digitálisan képzetlen emberek élnek legkevésbé az online tanfolyamok nyújtotta lehetôséggel. A kutatás folytatásaként érdemes lenne ezt a vizsgálatot más gazdasági térségekben is elkészíteni, leginkább azokon a régiókban, ahol a magas digitális kompetenciát igénylő foglalkozások fizetései nem térnek el jelentős mértékben egymástól a térségbe tartozó országok között.

Abstract. In this study, the challenges of digital development and its sectoral effects were examined between 2015 and 2017 in the EU Member States, based on data of OECD, Eurostat, and the World Bank. The connection between the countries' digital development and sector dominance was analyzed. I found - in line with international research - that in countries that belong to the developed group, the high value-added service sector is dominant. The statistics of developing countries' supported the assumption, that industry is the engine of the economy. The analysis of the underdeveloped countries revealed that agriculture and industry are the most important sectors compared to other countries. Measuring the demand of developed countries for ICT professionals, I examined the relationship of individuals with different digital competencies to one kind of selfeducation. In line with international research, my database showed that digitally unskilled people are the least likely to take advantage of online courses. As a continuation of the research, it would be worthwhile to carry out this study in other economic areas as well. Especially in areas where salaries for high-digital occupations do not differ significantly between countries in the region. 


\section{Bevezetés}

Minden korszaknak megvan a maga húzóágazata. Voltak évek, évtizedek amikor a vasút egyet jelentett a fejlődéssel. A 20. század első felében az autógyárak jelentették a gazdaság lelkét. Napjainkban az internet korában, szinte minden valamilyen módon a világhálózathoz kapcsolódik, vagy legalább digitalizált. Ezeknek az okos/digitális eszközöknek a használata már olyan szinten a hétköznapi élet szerves részét képezi, hogy aki nem tanulja meg használni, az nem csak a munkakeresésben kerülhet hátrányba, hanem a mindennapokban is. A digitalizáció magas foka megköveteli a vállalatoktól azt, hogy ha a lehető legkevesebb hibával és a leggyorsabb tempóval akarnak dolgozni - nem kiesve a versenyből -, akkor ne csak a(z összeszerelő) üzemeiket gépesítsék, hanem az irodáikat is. Ezeknek a digitalizált munkaeszközöknek a megfelelő használata viszont komoly háttértudást igényel. Ami a korábbi korszakokban a vas volt a sínhez, az autóhoz, azt most az ember a fejlődéshez.

A technológia gyors fejlődésének köszönhetően ma már olyan készségek megszerzésére kell a hangsúlyt helyezni, amivel könnyedén tanulhatunk, és melyek segítségével alkalmazkodhatunk a változásokhoz. Az oktatáspolitika országonként eltérő lehet, ahogyan a gazdaság szerkezete is. Hosszútávon azonban az átgondolatlan, nem a gazdaság szerkezetéhez, a jövőbeli célokhoz illő oktatási rendszer komoly gazdasági kárt okozhat. Hiányszakmák jöhetnek létre, illetve túlképzés jelentkezhet bizonyos területeken. Napjainkban, amikor az Európai Unión belül a munkaerő szabadon áramolhat, még nagyobb hangsúly helyeződik a megfelelő humánerőforrás gazdálkodásra,-amire hosszú távon az államok gyakorolják a legnagyobb hatást-, a kiművelt dolgozók felkutatására és megtartására.

\section{Kutatási célok}

A fordított kompetencia piramis [5] a fejlett országokra jellemző sajátosság, aminek köszönhetően mind a gazdaság, mind a humán erőforrás gazdálkodás területén több kérdés is felmerül, melyek megválaszolása ennek a cikknek a célja. Ezek a kérdések az alábbiak:

- A digitálisan fejlett országokban nagyobb igény van ICT szakemberekre, mint a fejlődő vagy fejletlen országokban?

- A digitalis kompetencia szint hogyan befolyásolja az online tanfolyamon való részvételt?

- A digitalis fejlettség és a szektor dominciája összefügg?

\section{Elméleti áttekintés}

A GDP (bruttó haza össztermék) egy jól bevált mutató, melynek segítségével meghatározhatjuk az országok gazdaságának állapotát. Értéke az egy területen, adott idő alatt előállított végső felhasználásra szánt termékek és szolgáltatások értékének az összege [6]. Bár a GDP-t számtalan kritikával illetik, és már több hasonló makro szintű mutató kidolgozása/alkalmazása zajlik, még mindig ez a legelfogadottabb közgazdasági index [16]. A gazdaság szektorainak múködése és a gazdaság egészének teljesítménye között összefüggés van. A mezőgazdaság vonatkozásában 
vizsgálta ezt Wang és szerzőtársai [19], akik szerint az agrárium és a gazdasági növekedés között pozitív kapcsolat van. Megállapították, hogy bár ennek a szektornak a részesedése a GDP-ből idővel jelentősen csökken, a mezőgazdaság növekedés hozzájárul többek között a kereskedelmen keresztül a gazdasági növekedéséhez. Ajmair [2] aki a gazdaság növekedésének és az ipar különböző ágazatainak kapcsolatát vizsgálta, arra jutott, hogy pozitív kapcsolat van a GDP növekedése és az ipar több ágazata között. Vizsgálata során az üzemanyag-kitermelést, a gyártást, az építőipart, a villamos, gáz és vízellátást, valamint a bányászatot elemezte. A kutatás során használt lineáris regresszió ezek közül csak a bányászattal nem mutatott pozitív kapcsolatot. Ajmair [2] vizsgálatában a GDP növekedésének 22\%-át az ipar növekedésével magyarázta. Az Ejaz Ghani és Homi Kharas [12] által készített tanulmány 136 ország reál GDP növekedését vetette össze a szolgáltatások hozzáadott értékének növekedésével. A szerzők szerint pozitív kapcsolat van a két változó között, vagyis azokban az országokban, ahol magas a szolgáltatás szektor növekedése, ott az általános gazdasági növekedés is magas. Az, hogy a szektorok mindegyike hatást gyakorol a gazdaság egészére, nem kérdéses, ami sokkal fontosabb az, hogy melyik mekkora mértékben befolyásolja azt.

Napjainkban szinte minden az informatika körül forog, ami a szolgáltatás szektor egyik, hanem a legfontosabb ága. Az eltolódás a szolgáltatások növekvő fontossága felé számos kölcsönhatás eredménye [17]. Az iparágak közötti termelékenységi különbségek, az iparágak közötti munkaerő-megosztás és a végső kereslet változása mind hozzájárult ahhoz, hogy a szolgáltatás szektor nagyobb hangsúlyt kapjon, mint a mezőgazdaság és az ipar. A szektor termelékenységének növekedése a jövőben tovább növelheti a szolgáltatás szektor alkalmazottainak a számát [18], és ezáltal a fontosságát. Az ICT (Information and Communication Technologies) ágazat továbbra is jelentős mértékben járul hozzá a termelékenység növekedéséhez David Byrne és Carol Corrado [4] szerint. A digitalizáció olyan mértékű, hogy a vállalatok számára a fó kihívást ma már nem a technológiai trendek vagy az újítások jelentik, hanem a kultúrájuknak és a kompetenciáiknak az átgondolása, azoknak az új, digitális munkamódszerekhez való igazítása [1]. Frey és Osborne [11] eredményei szerint, a jelenlegi amerikai foglalkoztatottaknak 47\%-a veszélyeztetetve van a számítógépesítés miatt. Bár ez részben ellent mond Schettkat és Yocarini [18] publikációjának, akik a szolgáltatás szektorban dolgozók számának emelkedését jósolták, de azt is figyelembe kell venni, hogy ebbe a szektorba az informatikán kívül más ágazatok is megtalálhatóak.

A technológia térdhódítása miatt napjainkban gyakran merül fel a kérdés, hogy mégis milyen digitális kompetenciák szükségesek a digitális korban a foglalkoztathatósághoz [7]. A digitális kompetencia Anusca Ferrari [3] szerint, az információs és kommunikációs technológia magabiztos, kritikus és kreatív felhasználása a munka, a tanulás, a szabadidő, a foglalkoztathatóság, a befogadás és / vagy a társadalomban való részvétel céljainak elérése érdekében. Az alkalmazottaknak általános ICT készségeket kell birtokolniuk ahhoz, hogy az új technológiákat a napi munkavégzés során használhassák [15]. Ezek elsajátíthatóak "on-the-job" és "off-the-job" módszerekkel is. A munkán kívüli tanulás megvalósulhat tanulmányutak, tréningek vagy önképzés formájában is [38]. Hansen és Reich [13] az önképzés azon fajtáját vizsgálta, melyet MOOC-nak (Massive Open Online Courses), vagy nyilvános online kurzusnak neveznek. Ezek a tömegek számára tervezett online tanfolyamok, amelyek bárki számára 
elérhetőek, minden végzettségre vonatkozó elvárás nélkül, viszont a teljes kurzus élményével, amit ingyen biztosít. Csupán internethozzáférés szükséges a részvételhez [39]. Hansen és Reich [13] véleménye szerint, azonban az efféle tanfolyamok inkább rontják, mint javítják a szociálisgazdasági helyzettel kapcsolatos oktatási eredményeket. Emanuel [8] is hasonlóan vélekedik. Szerinte az ilyen ingyenes tanfolyamokon résztvevők az átlagosnál iskolázottabbak közül kerülnek ki, ami tovább növeli a társadalmi, kompetenciabeli különbségeket.

\section{Adatok és módszerek}

Ahhoz, hogy elemezzem a digitális kompetencia, a humánerőforrás iránti kereslet és a gazdaság szektorainak kapcsolatát, szükségem volt egy átfogó adatbázisra. A felhasznált adatokat az Európai Statisztikai Hivatal (Eurostat), az OECD és a Világbank legfrissebb elérhető adatbázisaiból gyűjtöttem össze. A fejlődő országok IKT adatainak korlátozott hozzáférhetősége miatt csak az Európai Unió 28 tagállamát elemeztem 2015 és 2017 között [5], mivel jelenleg még nem hozzáférhetőek újabb adatok. A felhasznált adatok mennyisége és a vizsgált időszak hossza sem olyan nagy, mint az ideális lenne, de az adatbázis ennek ellenére elégséges lehet az arányok és irányok illusztrálására. A kutatás során az alábbi két témakör köré csoportosítható változókat használtam:

- makroökonómiai mutatók: gazdasági szektorok, munkaerő kereslet

- az egyének tulajdonságai: digitális kompetencia, önfejlesztés

Az Eurostat [9] készítette el az egyének digitális kompetenciák szerinti csoportosítást. Ehhez olyan digitális készségmutatókat állított össze, amelyek a 16-74 év közötti személyek internethasználatának vagy szoftverhasználatának szintjéhez kapcsolódóan négy különböző területet (információ, kommunikáció, problémamegoldás, szoftveres képességek) mért. Ezeknek az ismeretét több különböző feladat elvégzésének képességével határozták meg. Bizonyos esetekben ezeken a területeken belül csoportokat hoztak létre (egy könnyebb és egy nehezebb) a pontosabb vizsgálat érdekében. Amennyiben valaki csak egy tevékenységet tudott elvégezni (egy adott területről), akkor „átlagos” tudással rendelkezett (az adott a területen). Ha képes volt egynél több feladatot megfelelően végrehajtani, akkor „átlag feletti” tudása volt.

A részeredmények összesítésekor, négy csoportot különböztettek meg:

- nincs készség (digitális analfabéta): Semmilyen feladatot nem tudott megoldani, annak ellenére, hogy az elmúlt 3 hónapban legalább egyszer használt internetet.

- átlag alatti: Legalább egy, maximum három feladatot nem tudott megoldani a négy vizsgált területen.

- átlagos: Meg tudta oldani az összes feladatot, és legalább egyet „alap” szinten teljesített.

- átlag feletti: Teljesítette az összes feladatot „átlag feletti” szinten [9]. 
A digitális kompetencia felméréshez az Európai Statisztikai Hivatal biztosított egy minta kérdőívet az országok statisztikai hivatalainak, illetve az illetékes minisztériumainak, ami a mérés alapját képezhette. Ebből kiindulva azt feltételezhetjük, hogy nagyjából egységes önbevalláson alapuló felmérést töltöttek ki a résztvevők. Torzíthatja a mintát az is, hogy bizonyos országok elsődleges mintavételezési egységekként egyénen alapuló mintát használtak, míg mások a háztartásokat tekintették elsődleges mintavételi egységnek. A legtöbb országban a minta mérete 3000-6000 elem között alakult [9]. Fontos kiemelni az önbevalláson alapuló tesztek esetén a Dunning-Kruger hatást. Ennek értelmében azok az emberek, akik nem rendelkeznek kellő ismerettel egy adott témakörben hajlamosak letagadni ezen hiányosságukat, sőt a jártasságuk túlértékelésére is gyakran sor kerül [40].

Fontos kiemelni, hogy a technológia világában akár egy év alatt is komoly változások történhetnek, ám az átlag alatti és az átlagos digitális kompetenciát birtoklókra véleményem szerint ezek nem gyakorolnak jelentős hatást, mivel a legújabb technológiák használatához szükséges az átlag fölötti digitális írástudás megléte.

A makroökonómiai adatok forrását a Világbank [35] jelentette. Ebben az adatbázisban nem csak néhány évre visszamenőleg érhetőek el az európai országok szektorainak hozzáadott értéke a gazdaság egészéhez, hanem több kontinens, több országának és azok több évtizedes adatainak hozzáférése lehetséges. Ezeket az adatok a 2000-2018 közötti időszakra vonatkozóan gyújtöttem össze. A vizsgált periódus kezdetét azért tettem az ezredfordulóra, mivel egyes elemzők szerint [36], a XXI. század elején indult el igazán az internet fémjelezte technikai forradalom.

$\mathrm{Az}$ adatokat SPSS szoftverrel elemeztem. A változók közötti kapcsolat irányát és erősségét a Pearson-féle korrelációs együtthatóval határoztam meg. Az elemzés során a felvehető értékek halmaza 0 és 1 között alakul abszolút értékben. Ha az együttható értéke egyhez közel esik, akkor az azt jelenti, hogy erős kapcsolat van a két vizsgált változó között (együttmozgás). Amennyiben az értéke pozitív, akkor ugyanabba az irányba mozognak (együtt), míg negatív érték esetén a mozgás ellentétes irányú [10].

A kétmintás t-próbával azt vizsgáltam meg, hogy két külön mintában egy-egy valószínűségi változó átlagai szignifikánsan különböznek-e egymástól. A próba null hipotézise az, hogy a két csoport átlagai megegyeznek. A próba alkalmazásának két előfeltétele van, a normális eloszlás és a szórásegyezés. Amennyiben az SPSS által lefutatott Levene teszt eredménye nagyobb, mint 0,05, akkor megegyezik a szórás és alkalmazhatjuk a kétmintás t próbát, ellenkező esetben a Weich-féle d-próbát futtathatjuk le [14].

A vizsgált országok csoportosítását k-közép módszerrel végeztem el. A hasonló dolgok csoportosítása a klaszterezés, ami a vizsgált dolgok osztályozását jelenti. Ennek az az alapvető célja, hogy a megfigyelt egységeket aránylag homogén csoportokba rendezzük valamilyen szempont szerint. A hierarchikus klaszterezési módszerek közül az átlagos láncmódszer, illetve a Ward-módszerek alkalmazása a legnépszerűbb, de egyre inkább csak „kiegészítő” szerepet kapnak a nem hierarchikus módszerek mellett. A legjobb megoldás az, ha először egy hierarchikus módszert futtatunk le, melyből megtudjuk, hogy mennyi lenne a klaszterek ideális száma, és ez után a nem hierarchikus módszer futtatásakor, a korábban kapott értéket állítjuk be a csoportok 
számának. Ezen vizsgálat során a k-közép módszer önálló alkalmazása elegendő volt, mivel előre meghatározott számú csoport definiálása volt a cél [33].

\section{Eredmények}

\subsection{Az országok osztályozása a digitális kompetencia szerint}

Mivel ebben a kutatásban a digitális kompetencia áll a középpontban, így a klaszterek létrehozásához az SPSS számára az alábbi változókat definiáltam: alacsony, átlagos, átlag feletti digitális kompetencia. Ezáltal megtudtam, hogy milyen különbségek vannak a fejletlen, fejlődő és fejlett országok között.

A K-közép módszerrel az SPSS három klasztert generált 2015-ben és 2017-ben. A vizsgálat során úgy csoportosítottam az országokat, hogy azokat, amelyek a vizsgált periódus alatt klasztert váltottak kivettem a vizsgálatból (Svédország, Magyarország, Görögország, Egyesült Királyság, Horvátország, Olaszország), illetve a hiányos adatok miatt Málta és Ciprus sem szerepel a vizsgálatban. Így az alábbi csoportokat különböztettem meg:

- fejlett: Dánia, Finnország, Hollandia és Luxemburg

- fejlődő: Ausztria, Belgium, Csehország, Észtország, Franciaország, Litvánia, Németország, Portugália, Spanyolország, Szlovákia és Szlovénia

- fejletlen: Bulgária, Írország, Lengyelország, Lettország és Románia.

Fontos kiemelni, hogy hogyan alakulnak a különböző szintű digitális kompetenciájú egyének csoportjai méretük szerint a fejlett országok esetében. A legkisebb csoport az „alacsony” digitális kompetenciájú embereké. Ők vannak a legkevesebben. Majdnem kétszer több ember van az „átlagos” digitális kompetenciájú felhasználók csoportjában, mint az alsó klaszterben. Az „átlag feletti” felhasználók csoportja a legnagyobb. Közel másfélszerese az „átlagos” csoportnak [5].

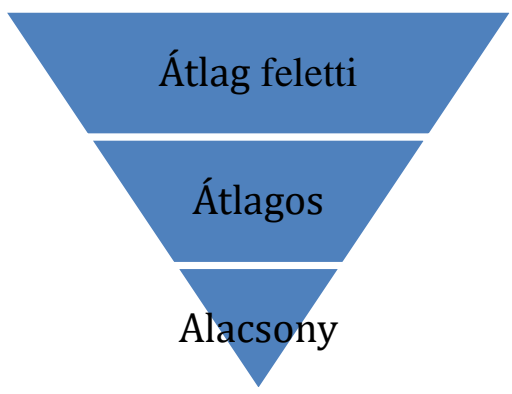

\section{1. ábra. A fejlett országok „fordított kompetencia piramisa"}

A legjelentősebb különbséget nem csupán az „átlag feletti” digitális kompetenciával rendelkező emberek csoportjának méretében van, hanem a digitálisan kompetens emberek számában is jelentős az eltérés. Ez azt jelenti, hogy a digitálisan fejlett országok lakói közül szinte mindenki birtokol valamilyen szintű digitális tudást [5]. 


\subsection{A digitális fejlettség és a szektorok dominanciájának kapcsolata}

Mivel a fordított kompetencia piramis sajátosságai érvényesülnek a fejlett országokban, ezért azt feltételeztem, hogy a nagyszámú átlag feletti tudást birtokló felhasználó miatt, már nem keresnek újabb ICT szakembereket.

Az Eurostat meghatározása szerint az ICT szakember olyan munkavállaló, aki képes ICTrendszerek fejlesztésére, üzemeltetésére és karbantartására, valamit az a munkavállaló is ide tartozik, akinek az ICT képezi a munkája fó részét [9].

Egyes tanulmányok szerint ezen szakemberek felkutatása már most is nehézséget jelent a vállalatok számára, de a későbbiekben az ICT szakemberek megtartása, valamint a jövőbeli új kollégák toborzása és betanítása még nagyobb kihívást fog jelenteni a szervezetek számára [37].

A 1. táblázatban kétmintás t próbával megvizsgáltam azt, hogy a fejlett országokban, vagy a fejlődő és fejletlen országokban van-e szükség további képzett ICT szakemberekre (toboroztak vagy próbáltak toborozni esetleg volt nehezen betölthető ICT szakembert igénylő állásuk).

\begin{tabular}{|c|c|c|c|c|c|c|c|c|c|}
\hline & \multirow[t]{2}{*}{$\mathrm{F}$} & \multirow[t]{2}{*}{ Sig. } & \multirow[t]{2}{*}{$\mathrm{t}$} & \multirow[t]{2}{*}{$\mathrm{df}$} & \multirow[t]{2}{*}{$\begin{array}{l}\text { Sig. } \\
(2- \\
\text { tailed) }\end{array}$} & \multirow[t]{2}{*}{$\begin{array}{c}\text { Mean } \\
\text { Difference }\end{array}$} & \multirow[t]{2}{*}{$\begin{array}{l}\text { Std. Error } \\
\text { Difference }\end{array}$} & \multicolumn{2}{|c|}{$\begin{array}{c}99 \% \\
\text { Confidence } \\
\text { Interval of the } \\
\text { Difference }\end{array}$} \\
\hline & & & & & & & & Lower & Upper \\
\hline $\begin{array}{c}\text { Vállalatok, akik kerestek, vagy } \\
\text { próbáltak keresni ICT } \\
\text { szakembert }\end{array}$ & 3,207 & 0,077 & 3,747 & 76 & 0,000 & 2,902 & 0,774 & 856, & 4,947 \\
\hline $\begin{array}{l}\text { Vállalatok, ahol volt nehezen } \\
\text { betölthető ICT pozíció }\end{array}$ & 0,000 & 0,994 & 4,874 & 75 & 0,000 & 2,477 & 0,508 & 1,134 & 3,820 \\
\hline
\end{tabular}

1. táblázat. Kétmintás t próba a fejlett országok ICT szakemberek iránti igényének vizsgálatára

$\mathrm{Az}$ empirikus $\mathrm{t}$ érték mind a két esetben nagyobb, mint a kritikus $\mathrm{t}$ érték $(2,36)$, így azt mondhatjuk, hogy az eltérés nem a véletlennek köszönhető, vagyis a fejlett országokban, nagyobb szükség van új ICT specialistákra, mint a fejlődő és fejletlen országokban.

Oroszországban az IT diplomások több, mint 40\%-a nem talál magának munkát az oktatás (alacsony) színvonala miatt [25], míg Csehországban a frissen végzett IT diplomások „betanítása”, túlságosan költséges a vállalatok számára [24]. Ezen kutatások magyarázatot jelenthetnek az 1 . táblázat adataira abban a formában, hogy bár feltételezhetően a fejlett EU-s országok is képeznek ICT szakembereket, de ezen képzések színvonala nem minden esetben felel meg a piac elvárásainak, így a kieső munkaerő pótlására külföldről megfelelő tudással és tapasztalattal rendelkező szakembereket igyekeznek szerződtetni.

Ebből arra következtethetünk, hogy a fejlett országokban magasabb a hozzáadott érték a szolgáltatás szektorban,-hiszen az ICT éppen ennek a húzóágazata-,mint a többi ország esetében. Ennek a feltételezésnek a vizsgálatára ismét egy kétmintás t próbát végeztem el. Ezt szemlélteti a 2. táblázat. 


\begin{tabular}{|c|c|c|c|c|c|c|c|c|c|}
\hline & \multirow[t]{2}{*}{$\mathrm{F}$} & \multirow[t]{2}{*}{ Sig. } & \multirow[t]{2}{*}{$\mathrm{t}$} & \multirow[t]{2}{*}{ df } & \multirow[t]{2}{*}{$\begin{array}{l}\text { Sig. } \\
(2- \\
\text { tailed })\end{array}$} & \multirow[t]{2}{*}{$\begin{array}{c}\text { Mean } \\
\text { Difference }\end{array}$} & \multirow[t]{2}{*}{$\begin{array}{l}\text { Std. Error } \\
\text { Difference }\end{array}$} & \multicolumn{2}{|c|}{$\begin{array}{l}\text { 99\% Confidence } \\
\text { Interval of the } \\
\text { Difference }\end{array}$} \\
\hline & & & & & & & & Lower & Upper \\
\hline szolgáltatás & 6,137 & 0,14 & 7,309 & 492 & 0,000 & 5,43 & 0,74 & 3,5 & 7,35 \\
\hline mezőgazdaság & 14,367 & 0,000 & $-5,674$ & 492 & 0,000 & $-1,23$ & 0,22 & $-1,79$ & $-0,67$ \\
\hline ipar & 0,269 & 0,604 & $-7,684$ & 492 & 0,000 & $-4,73$ & 0,62 & $-6,22$ & $-3,14$ \\
\hline
\end{tabular}

2. táblázat. A fejlett országok szektorainak kétmintás t próbája

A szolgáltatás szektor számított t érték nagyobb volt a kritikus t értéknél $(2,33)$, vagyis azt mondhatjuk, hogy a fejlett országokban a többi országgal ellentétben magasabb a szolgáltatások hozzáadott értéke, míg a többi szektor esetén nem vonhatunk le ilyen következtetéseket.

Szirmai eredményei is alátámasztják a számításaimat. Szerinte a fejlett országokban a szolgáltatások adják a GDP 70\%-át [21].

A fejlődő országokban a hozzáadott érték, tudás, magasabb, mint a fejletlen országokban, így feltételezhető, hogy az ipar (ami tudásigényesebb, mint az agrárium, de nem annyira tudásigényes, mint a szolgáltatás szektor) lesz a gazdaság húzó szektora. Ennek a feltételezésnek a vizsgálatát szemlélteti a 3. táblázat.

\begin{tabular}{|c|c|c|c|c|c|c|c|c|c|}
\hline & \multirow[t]{2}{*}{$\mathrm{F}$} & \multirow[t]{2}{*}{ Sig. } & \multirow[t]{2}{*}{$\mathrm{t}$} & \multirow[t]{2}{*}{$\mathrm{df}$} & \multirow[t]{2}{*}{$\begin{array}{c}\text { Sig. } \\
(2- \\
\text { tailed) }\end{array}$} & \multirow[t]{2}{*}{$\begin{array}{c}\text { Mean } \\
\text { Difference }\end{array}$} & \multirow[t]{2}{*}{$\begin{array}{l}\text { Std. Error } \\
\text { Difference }\end{array}$} & \multicolumn{2}{|c|}{$\begin{array}{l}\text { 99\% Confidence } \\
\text { Interval of the } \\
\text { Difference }\end{array}$} \\
\hline & & & & & & & & Lower & Upper \\
\hline szolgáltatás & 35,481 & 0,000 & $-1,054$ & 492 & 0,292 & $-0,6$ & $-0,57$ & $-2,08$ & 0,87 \\
\hline mezőgazdaság & 44,726 & 0,000 & $-4,484$ & 492 & 0,000 & $-0,72$ & 0,16 & $-1,13$ & $-0,3$ \\
\hline ipar & 2,509 & 0,114 & 5,415 & 492 & 0,090 & 2,5 & 0,46 & 1,3 & 3,7 \\
\hline
\end{tabular}

3. táblázat. A fejlődô országok szektorainak kétmintás t próbája

Sem a mezőgazdaság, sem a szolgáltatás esetében nem lehetett a Levene teszt eredményeit figyelembe venni, mivel a hozzájuk tartozó szignifikancia szintek 0,05 alatt voltak, azonban az ilyenkor használható Welch-féle d-próba sem hozott eredményt. Az ipar esetében viszont a kritikus t érték $(2,33)$ alacsonyabb volt a számított t értéknél, ezért kijelenthetjük, hogy ez a szektor a domináns a fejlődő országokban. Más kutatások szerint is az ipar a növekedés fontos mozgatórugója a legtöbb fejlődő országban. (A magyar húsipari középvállalkozások információs rendszerek iránti kereslete is alátámasztja ezt [27].) Egyértelműen viszont nem nevezhetjük a 
fejlődés motorjának, mivel a tőkeintenzitást és a munkatermelékenységet tekintve az adatok ezt nem támasztják alá [21].

A fejletlen országok esetében azzal a feltételezéssel éltem, hogy a legkevésbé tudásigényes szektor a mezőgazdaság lesz a húzóágazat. Ahhoz, hogy ezt matematikailag is alátámaszthassam kétmintás t próbát alkalmaztam, aminek az eredményét a 4. táblázat szemlélteti.

\begin{tabular}{|c|c|c|c|c|c|c|c|c|c|}
\hline & \multirow[t]{2}{*}{$\mathrm{F}$} & \multirow[t]{2}{*}{ Sig. } & \multirow[t]{2}{*}{$\mathrm{t}$} & \multirow[t]{2}{*}{$\mathrm{df}$} & \multirow[t]{2}{*}{$\begin{array}{l}\text { Sig. } \\
(2- \\
\text { tailed })\end{array}$} & \multirow[t]{2}{*}{$\begin{array}{c}\text { Mean } \\
\text { Difference }\end{array}$} & \multirow[t]{2}{*}{$\begin{array}{l}\text { Std. Error } \\
\text { Difference }\end{array}$} & \multicolumn{2}{|c|}{$\begin{array}{l}\text { 99\% Confidence } \\
\text { Interval of the } \\
\text { Difference }\end{array}$} \\
\hline & & & & & & & & Lower & Upper \\
\hline szolgáltatás & 1,331 & 0,242 & $-8,645$ & 492 & 0,000 & $-5,77$ & 0,67 & $-7,49$ & $-4,04$ \\
\hline mezőgazdaság & 86,169 & 0,000 & 10,95 & 492 & 0,000 & 2 & 0,18 & 1,54 & 2,48 \\
\hline ipar & 0,434 & 0,511 & 6,571 & 492 & 0,000 & 3,76 & 0,57 & 2,28 & 5,24 \\
\hline
\end{tabular}

4. táblázat. A fejletlen országok szektorainak kétmintás t próbája

Az empirikus t érték a szolgáltatások esetén alacsonyabb, mint a kritikus t érték $(2,33)$, vagyis az átlagok különbözőségét csak a véletlennek tudjuk be. Az ipar esetében a számított t érték viszont magasabb, mint a kritikus t érték, így azt mondhatjuk, hogy a fejletlen országok esetében az ipar a meghatározó. A mezőgazdaság tekintetében bár a Levene teszt eredményeit nem lehetett figyelembe venni, mivel ennek a szignifikancia szintje 0,000 volt, az ilyenkor alkalmazható Welchféle d-próba során szignifikáns eredményt kaptam, ugyanis az empirikus t érték 6,747 volt, ami magasabb a kritikus t értéknél. Ennek tekintetében azt mondhatjuk, hogy a mezőgazdaság is fontos szerepet játszik a fejletlen országokban.

Timmer [22] szerint, ahogyan egy országban nő az egy főre eső bevétel, úgy csökken a mezőgazdaság részesedése a GDP-ből. Ez is alátámaszthatja azt, hogy a fejletlen országokra jellemző az agrárium „túlsúlya”. Bár Európa egyetlen országa sem tartozik az LDC (Least Developed Countries - legfejletlenebb országok) tagok közé, ennek ellenére elmondható, hogy ezekben a többségében afrikai országokban a mezőgazdaság jelenti a gazdaság gerincét. (Az agráriumot bár több veszély is fenyegeti [31], a gazdálkodást támogató IOT rendszerek [26] és a megfelelő inputanyagok optimális felhasználásával a Föld képes lehet akár 8-10 milliárd ember élelmiszerigényét is kielégíteni [32].) Az Egyesült Nemzetek Szövetsége (ENSZ) szerint ezen államok GDP-jének 30-60\% adja ez a szektor [23]. Erre alapozva, azt feltételezem, ha nem is ilyen mértékű az agrárium túlsúlya az EU fejletlen országaiban, de jelenetős szerepe lehet. Fontos azonban megjegyezni, hogy az ICT a mezőgazdaság hatékonyságát is jelentősen növelheti, ami különösen azokban az országokban fontos, ahol a kis és középvállalkozások kulcsszerepet játszanak ebben a szektorban [41].

Látva a fejlett országok továbbra is fennálló igényét az ICT szakemberekre, azt feltételeztem, hogy a kevésbé képzett emberek élni fognak a tanulás nyújtotta fejlődés lehetőségével, hiszen az 
internet többek között számtalan az informatika területéhez kapcsolódó betanító, „korrepetáló” anyagot tesz elérhetővé.

$\mathrm{Az}$ online tanfolyamon való részvétel vizsgálatával (2. ábra) a különböző kompetenciájú személyek internetes tanuláshoz füződő viszonyait, fejlődésre való igényüket elemeztem.

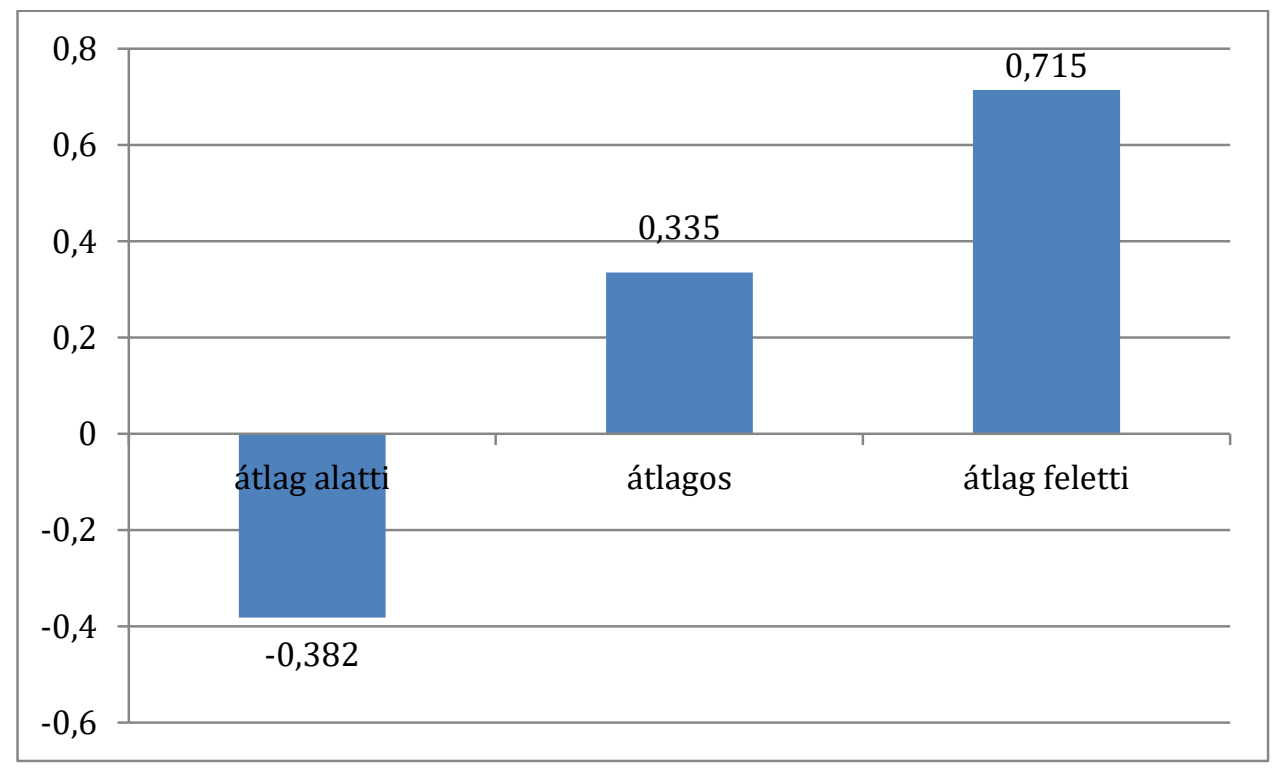

2. ábra. Az online tanfolyam és digitális kompetencia szintek korrelációs együtthatói

A korrelációs vizsgálat eredménye 99\%-os valószínúséggel megállapította, hogy az alacsony kompetenciájú személyek nem élnek ezzel a lehetőséggel, míg az átlagos és átlag feletti ismeretekkel rendelkező személyek annál inkább. A tanfolyamon való részvétel, nem jelent egyet a tudás megszerzésével is, ezért fontos megvizsgálni annak a hatékonyságát is [29].

Az általam mért eredményekhez hasonlókat publikált Ho és társai [20], aki azt vizsgálta meg, hogy a Harvard University és a MIT által kínált 68 különböző ingyenes online kurzust 2 éven keresztül kik vették igénybe. A szerzők eredményei szerint a résztvevők $70 \%$ rendelkezett legalább BSc (főiskolai) végzettséggel, és mint egy korábbi kutatás eredményéből kiderült, a digitális kompetencia szintje és az iskolai végzettség szintje nem feleltethető meg egyértelmúen egymásnak, viszont a felsőfokú végzettséggel rendelkezők jó eséllyel birtokolnak legalább általános digitális kompetenciát [34].

Ezen eredmények tekintetében elmondhatjuk, hogy ez a hozzáállásbéli hiányosság nem segít pótolni a szükséges szakembereket, akiket feltehetően emiatt a fejlődő és fejletlen országokból toboroznak, -amiben a mesterséges intelligencia a közeljövőben még több segítségét nyújthat [30], - ami komoly kihívást okozhat a vállalatok számára [28]. Ennek köszönhetően egyfajta kényszer pályára is állhat a fejlődő és a fejletlen országok gazdaság, vagyis, ha szeretné is a hangsúlyt egy másik szektorra helyezni, az emberei erőforrás hiányosságai miatt ezt nem tudja megtenni. 


\section{Következtetések és javaslatok}

Kutatásom során azt tapasztaltam, hogy hiába érvényesülnek a digitálisan kompetens országokban a fordított kompetencia piramis sajátosságai, továbbra is jelentős igény van újabb ICT szakemberekre. A nagymértékű kereslet miatt azt feltételeztem, hogy a szolgáltatás szektor a gazdaság motorja ezekben az országokban. Ezt a felvetésemet kétmintás t próbával teszteltem. A statisztikai mutatószámok és korábbi kutatások is alátámasztották az elképzelésemet, vagyis a fejlett országokban a többi országgal ellentétben, magasabb a szolgáltatás szektor jelentősége. A többi szektor esetén nem vonhatunk le ilyen következtetést. Ami a fejlődő csoportot illeti, a nemzetközi kutatásokkal megegyezően a statisztikai vizsgálat alátámasztotta azt a feltevésemet, hogy az ipar (ami tudásigényesebb, mint az agrárium, de nem annyira tudásigényes, mint a szolgáltatás szektor) lesz a gazdaság húzó szektora. A fejletlen országok esetében azzal a feltételezéssel éltem, hogy a legkevésbé tudásigényes szektoron, a mezőgazdaságon lesz a hangsúly. A kétmintás t próba részben megerősítette a korábbi hipotézisemet. A többi országhoz képest a mezőgazdaság és az ipar számít a fejletlen országok motorjának.

Látva a fejlett országok továbbra is fennálló igényét az ICT szakemberekre, azt feltételeztem, hogy a kevésbé kompetens emberek élnek az önfejlesztés lehetőségével, és törekednek az új ismeretek megszerzésére, hiszen az online elérhető informatikai tananyagok sok területet lefedő és részletes útmutatást nyújtanak. Ezért megvizsgáltam, hogy a különböző digitális kompetenciájú egyének és az online kurzuson való részvétel között milyen kapcsolat van. Nemzetközi kutatások is megerősítették az eredményemet, miszerint, a digitálisan képzetlen emberek veszik legkevésbé igénybe ezt a lehetőségét. A másik két csoport tagjai viszont előszeretettel képzik magukat online. Ez oda vezethet, hogy a digitálisan képzett országok az újabb ICT szakembereiket külföldről toborozhatják, így a fejlődő és a fejletlen országok egyfajta kényszer pályára kerülhetnek, hiszen ha szeretnének egy diverzifikáltabb gazdaságot, vagy egy szektoriális váltást, akkor azt nem, vagy csak komoly nehézségek árán tudnák kivitelezni.

A kutatás folytatásaként az országok szerinti csoportosítását érdemes lenne más gazdasági térségekben is megvizsgálni. Főleg azokon a területeken lenne érdekes ezt elemezni, ahol a magas digitális kompetenciát igénylő foglalkozások fizetései nem térnek el jelentős mértékben egymástól a térségbe tartozó országok között. Az Európai Unión belüli szabad munkaerő áramlás értelmében, egy „top” digitálisan kompetens programozó az „agyelszívás” keretében, a magasabb fizetésért cserébe országot válthat, így az őt „kiképző” országot kényszer pályára állíthatja (a kevésbé tudásigényes szektorokra kell helyeznie a hangsúlyt), míg hasonló körülmények mellett, egyfajta „természetes szelekció” mutatkozhatna a domináns szektor tekintetében.

\section{Hivatkozások}

[1] Accenture Technology Vision (2016): People First: The Primacy of People in a Digital Age

[2] Ajmair M. (2014): MPACT OF INDUSTRIAL SECTOR ON GDP(PAKISTAN CASE), European Journal of Contemporary Economics and Management May 2014 EditionVol.1 No.1 , Doi: 10.19044/elp.v1no1a8 
[3] A. Ferrari (2013): DIGCOMP: A Framework for Developing and Understanding Digital Competence in Europe

[4] D. Byrne, C. Carol (2017): "ICT Services and their Prices: Whatdo they tell us about Productivity and Technology?," Finance and Economics Discus-sion Series 2017-015. Washington: Board of Governors of the Federal Reserve System,https://doi.org/10.17016/FEDS.2017.015r1.

[5] A. Csordás, I. Füzesi (2019): Digitális kompetenciaszintek valamint a munkanélküliség és a vállalati továbbképzések közötti kapcsolatok az Európai Unióba, International Journal of Engineering and Management Sciences (IJEMS) Vol. 4. (2019). No. 3, DOI: 10.21791/IJEMS.2019.3.19.

[6] J. Dhiraj, K.S. Nair, V. Jain (2015): Factors Affecting GDP (Manufacturing, Services, Industry):An Indian Perspective, ISSN 2348-0661 Print (C) 2015 Symbiosis Centre for Management Studies, Pune Annual Research Journal of Symbiosis Centre for Management Studies, Pune, Vol. 3, April 2015, pp. 38-56

[7] R. Dubey, A. Gunasekaran (2015): Education and training for successful career in big data and business analytics, Industrial and Commercial Training, Vol. 47 No. 4, pp. 174-181.

[8] E.J. Emanuel (2013). MOOCs taken by educated few. Nature, 503(7476), 342-342. doi:10.1038/503342a

[9] Eurostat [2019) [Online]. Available: https://ec.europa.eu/eurostat/cache/metadata/en/tepsr_sp410_esmsip2.htm. [Accessed: 14 Jul.2019].

[10] A. Field (2013): Discovering statistics using IBM SPSS Statistics paperback (4th ed.). Thousand Oaks, CA, USA: SAGE Publications.

[11] C.B. Frey, M.A. Osborne (2013): The Future of Employment: How Susceptible are Jobs to Computerization?, University of Oxford.

[12] E. Ghani, H. Kharas (2010): The Service Revolution, www.worldbank.org/economicpremise

[13] J.D. Hansen, J. Reich (2015): Democratizing education? Examining access and usage patterns in massive open online courses. Science, 350(6265), 1245-1248. doi:10.1126/science.aab3782

[14] G. Howell (2012): Statistical Methods for Psychology, Wadsworth; International ed of 8th revised ed edition, ISBN-10: 1111840857

[15] INLFUENCE\&POLICY, AI GROUP (2018)

[16] Z. Kovacic, M. Giampietro (2015): Beyond "beyond GDP indicators:" The need for reflexivity in science for governance, Ecological Complexity 21 (2015) 53-61, http://dx.doi.org/10.1016/j.ecocom.2014.11.007 
[17] P.T. Marcel, I. Robert, O. Mary, V.A. Bart (2011): "Productivity and Economic Growth in Europe: A Comparative Industry Perspective," International Productivity Monitor, Centre for the Study of Living Standards, vol. 21, pages 3-23, Spring.

[18] R. Schettkat, L. Yocarini (2006): The shift to services employment:A review of the literature, Structural Change and Economic Dynamics17 (2006) 127-147

[19] X.Z. Wang, S.L. Wu, F. Gao (2010): The relationship between economic growth and agricultural growth: The case of China. Paper presented at International Conference on E-Business and E-Government (ICEE), Guanghou, China

[20] A.D. Ho, I. Chuang, J. Reich, C. Coleman, J. Whitehill, C. Northcutt, I.J. Williams, J. Hansen G. Lopez, R. Petersen (2015): HarvardX and MITx: Two years of open online courses (HarvardX Working Paper No. 10). doi:10.2139/ssrn.2586847

[21] A. Szirmai (2012): Industrialisation as an engine of growth in developing countries, 1950-2005. Structural Change and Economic Dynamics, 23(4), 406-420. doi:10.1016/j.strueco.2011.01.005

[22] C.P. Timmer (2009): A World without Agriculture: The Structural Transformation in Historical Perspective. Washington, D.C.: American Enterprise Institute Press.

[23] United Nations Ministerial Conference of the Least Developed Countries (2007): Making Globalization Work for the LDCs Istanbul, 9-11 July 2007

[24] P. Ducek, L. Nedomova, M. Maryska (2012): Differences between Offer and Demand on the ICT specialist's Czech Labor Market, Organizacija, Volume 45, Number 6, November-December 2012

[25] G.L. Abdulgalimov (2014): Progress of information society in Russia and deficit of staff potential Life Science Journal 2014;11(8)

[26] M. Tóth, J. Felföldi, R. Szilágyi (2019): Possibilities of IoT based management system in greenhouses, Georgikon for Agriculture $23: 3$ pp. 43-62. , 20 p.

[27] I. Füzesi, J. Felföldi, P. Lengyel (2018): Információs rendszerek alkalmazásának vizsgálata a magyarországi húsipari vállalkozásoknál, ACTA CAROLUS ROBERTUS 8 : 1 pp. 65-76. , 12 p.

[28] M. Ujhelyi, Filep R (2019): Szervezeti változások vezetése, Vezető és menedzser : Emlékkötet Farkas Ferenc születésének 70. évfordulójára,pp. 230-237.

[29] P. Lengyel, M. Herdon, J. Pancsira, G. Rathonyi, I. Fuzesi (2017): THE EFFECTIVENESS OF THE E-LEARNING APPLICATIONS: ASSESSMENT OF THE SERVICE QUALITY USING BINOMINAL LOGISTIC REGRESSION, JOURNAL ON EFFICIENCY AND RESPONSIBILITY IN EDUCATION AND SCIENCE $10: 2$ pp. 51-57. , 7 p. (2017)

[30] B. Hmoud, L. Várallyai (2019): Will Artificial intelligence Take Over HumanResources Recruitment and Selection?, NETWORK INTELLIGENCE STUDIES VII : 13 pp. 21-30. , $10 \mathrm{p}$. 
[31] J. Popp, J. Oláh, A. Kiss, Z L akner (2019): Food security perspectives in Sub-Saharan Africa, AMFITEATRU ECONOMIC 21 : 51 pp. 361-376. , 16 p.

[32] N. Novák (2019): A mütrágyafelhasználás piactérképének elemzése, INTERNATIONAL JOURNAL OF ENGINEERING AND MANAGEMENT SCIENCES / MÚSZAKI ÉS MENEDZSMENT TUDOMÁNYI KÖZLEMÉNYEK $4: 4$ pp. 381-388. , 8 p.

[33] L. Sajtos, A. Mitev (2007): SPSS Kutatási és adatelemzési kézikönyv. Alinea Kiádó

[34] O.E. Hatlevik, G. Ottestad, I. Throndsen (2014): Predictors of digital competence in 7th grade: a multilevel analysis. Journal of Computer Assisted Learning, 31(3), 220-231.

[35] Világbank, https://data.worldbank.org, [Accessed: 14. 03. 2020].

[36] P. Gloor (2000): Making the e-business transformation, Springer-Verlag, London.

[37] A. Pazur, K. Anicic, B. Divjak, K. Arbanas[38 (2017). Preparing ICT Graduates for RealWorld Challenges: Results of a Meta-Analysis. IEEE Transactions on Education, 60(3), 191-197. doi:10.1109/te.2016.2633959

[38] J. Kárpátiné Daróczi, J. Vágány, É. Fenyvesi (2016): Fejlődünk, hogy fejlődhessünk? avagy milyen önképzési módszereket részesítenek előnyben a mikro- és kisvállalkozások vezetői napjainkban Magyarországon? Vezetéstudomány - Budapest Management Review, 47 (12). pp. 72-82. DOI 10.14267/VEZTUD.2016.12.07

[39] D. Jansen, R. Schuwer (2015): Institutional MOOC strategies in Europe,EADTU, February 2015

[40] D. Dunning (2011): The Dunning-Kruger effect: On being ignorant of one's own ignorance. In J. M. Olson \& M. P. Zanna (Eds.), Advances in experimental social psychology. Advances in experimental social psychology, Vol. 44 (p. 247-296). Academic Press. https://doi.org/10.1016/B978-0-12-385522-0.00005-6

[41] Sz. Botos, J. Felföldi, L. Várallyai, Á. Péntek, R. Szilágyi (2018): ANALYSIS THE ADVANCED ICT USAGE OF THE HUNGARIAN SME SECTOR FOR PREPARING A DOMESTIC AGRI-FOOD RESEARCH APSTRACT - APPLIED STUDIES IN AGRIBUSINESS AND COMMERCE $11:$ 3-4 pp. 147-154. , 8 p. 